\title{
Nationalism, Language, and Muslim Exceptionalism
}




\section{HANEY FOUNDATION SERIES}

A volume in the Haney Foundation Series, established in 1961 with the generous support of Dr. John Louis Haney 


\section{NATIONALISM, LANGUAGE, AND MUSLIM EXCEPTIONALISM}

Tristan James Mabry

\section{$\overline{\text { PENN }}$}

UNIVERSITY OF PENNSYLVANIA PRESS 


\section{Copyright @ 2015 University of Pennsylvania Press}

All rights reserved. Except for brief quotations used for purposes of review or scholarly citation, none of this book may be reproduced in any form by any means without written permission from the publisher.

Published by

University of Pennsylvania Press

Philadelphia, Pennsylvania 19104-4112

Printed in the United States of America

on acid-free paper

$$
\begin{array}{llllllllll}
1 & 3 & 5 & 7 & 9 & 10 & 8 & 6 & 4 & 2
\end{array}
$$

\section{Library of Congress Cataloging-in-Publication Data}

Mabry, Tristan James.

Nationalism, language, and Muslim exceptionalism / Tristan James Mabry. - 1st ed. p. cm. - (Haney Foundation series)

Includes bibliographical references and index.

ISBN 978-0-8122-4691-9 (hardcover : alk. paper)

1. Nationalism-Religious aspects-Islam-Case studies. 2. Group identity-Religious aspects-Islam-Case studies. 3. Language and culture-Political aspects-Case studies. 4. Islamic fundamentalism-Case studies. 5. Separatist movements-Case studies. 6. Exceptionalism-Case studies. I. Title. II. Series: Haney Foundation series. JC311.M24 2015

$320.540917^{\prime} 67-\mathrm{dc} 23$ 